\title{
Clay mineralogy of the Upper Paleocene and Eocene clay sediments in Denmark
}

\author{
ZHANG DEYU
}

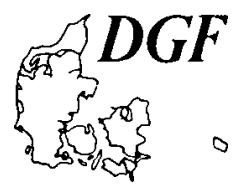

Zhang Deyu: Clay mineralogy of the Upper Paleocene and Eocene clay sediments in Denmark. Bull. geol. Soc. Denmark, vol. 36, pp. 249-258, Copenhagen, December, 31st, 1987 https://doi.org/10.37570/bgsd-1988-36-06

\begin{abstract}
The clay mineralogy of the Upper Paleocene and Eocene "plastic clay" sediments has been investigated from a new borehole in the Great Belt of Denmark. Predominant smectite, with small amounts of illite, kaolinite and, in the Holmehus $\mathbf{F m}$., chlorite, have been identified in the Upper Paleocene sediments. Abundant smectite and increased amounts of kaolinite and illite, with little chlorite, are present in the Eocene sediments. The Tertiary section of the borehole has been divided into two zones; one dominated by smectite with trace amount of kaolinite, including the Upper Paleocene and the R1-R3 Beds of Røsnæs Clay Fm.; another characterized by the distinct increase of kaolinite and the relative decrease of smectite, including the R4-R6 and the L1-L $A$ Beds of Eocene sediments. Regionally, smectite content decreases, while kaolinite and illite increase from the north to the south and southeast in the Eocene sediments. No clear trend has been recognized in the Upper Paleocene sediments.

The effect of material source, palaeoclimate and depositional environment on clay mineral distribution is discussed. The high content of smectite is considered to be mainly attributed to the alteration and/or weathering of volcanic material, contributions of smectitic clay from carbonate terrains and far trans-ported suspended matter from north-northwest. The change in climatic conditions may also be of importance. The distinct increase in kaolinite content of the Eocene sediments is thought to be related to a clastic source to the south and southeast and to the warmer climatic conditions.
\end{abstract}

Zhang Deyu, First Institute of Oceanography, National Bureau of Oceanography, P. O. Box 98, Qingdao, Chian; and Institute for Applied Geology, Technical University of Denmark, DK-2800 Lyngby, Denmark. July 31st, 1986.

The Upper Paleocene and Eocene marine sediments of Denmark are mainly composed of clay. Thus, the study of their clay mineralogy is of significant interest.

The first systematic investigation of clay minerals of the Upper Paleocene and Eocene sediments of Denmark was made by Tank (1963). He divided them into three mineral zones, based on the examination of 108 samples, and suggested that the main clay mineral, smectite, was chiefly derived from a carbonate terrain bordering the Fannoscandian shield and from the alteration of volcanic material. Heilmann-Clausen et al. (1985) have investigated the lithology and lithostratigraphy of the Upper Paleocene and Eocene sediments from Denmark, including a description and discussion of clay mineral distribution. Other investigations on the Paleogene clays of Denmark were made by Unmack (1949), Graff-Petersen (1955), Madirazza et al. (1969), Nielsen (1974) and Thiede et al. (1980). Their studies show that the most important clay mineral in the
Paleogene clays is smectite, followed by illite and kaolinite.

This paper studies the clay mineral distribution of borehole 83101 and compares it with previous studies, mainly those of Heilmann-Clausen et al. (1985). This borehole was drilled in the Great Belt by the Danish Geotechnical Institute in 1983 (see Fig. 4). The Tertiary sequences encountered in the borehole are of Late Paleocene to Middle Eocene age. The general geology, lithology, lithostratigraphy and depositional environment have been investigated by Nielsen et al. (1986) (Fig. 1 ), in which brief comment was made to the clay mineral study carried out by the present author.

The main purpose of the article is to present the detailed results from the clay mineral investigation and to discuss the effect of palaeoclimate, material source and depositional environment on the distribution patterns of clay minerals of the Upper Paleocene and Eocene sediments in the Danish Part of the North Sea Basin. 


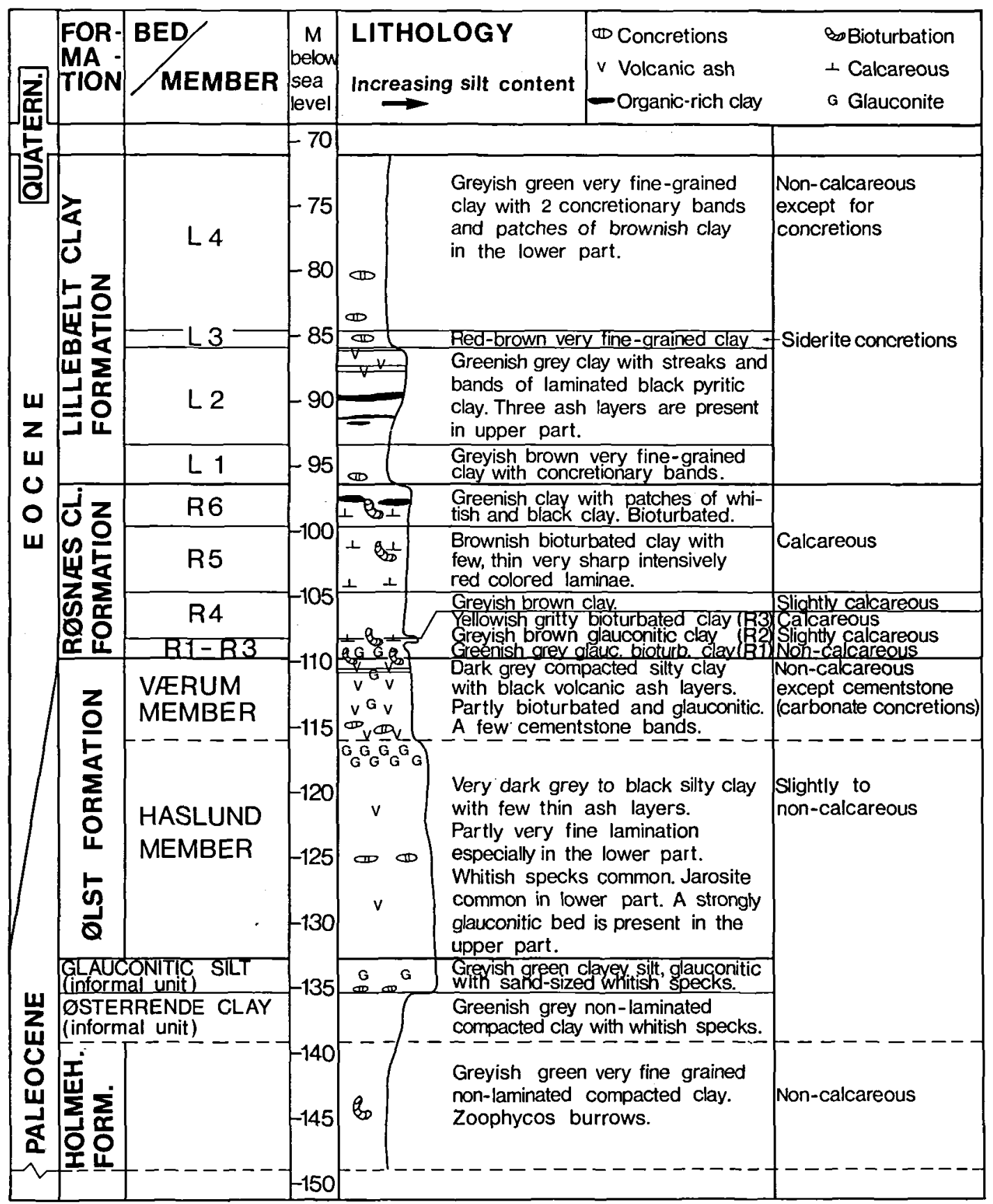

Fig. 1. Lithology and lithostratigraphy of Upper Palcocene to Middle Eocene formations in Borehole 83101 (after Nielsen et al., 1986).

\section{Experimental techniques}

33 samples from the Tertiary section of the borehole were subjected to grain size analysis and the $\mathrm{X}$-ray determination of clay minerals.
Grain size distribution down to less than 0.2 microns was determined by a Sedigraph 5000ET (Stein, 1985). The sand fraction larger than 63 microns was sieved.

Oriented smear-slide preparations (Gibbs, 
1971) were made of air-dried samples, which were glycollated with ethylene glycol vapour at $60^{\circ} \mathrm{C}$ for 24 hours and subsequently heated to $300^{\circ} \mathrm{C}$ and $550^{\circ} \mathrm{C}$ for 2 hours, and then run respectively on a Philips X-ray diffractometer with a graphite monochromator, using $\mathrm{Cu} \mathrm{K}$-alpha radiation and an automatic divergence slit system.

The identification of clay minerals was based on their basal reflections, according to Brown (1961) and Brindley \& Brown (1980). Reflections at about $17.0 \AA, 8.5 \AA, 5.6 \AA$ and $2.85 \AA$ on the glycollated-diffractograms were attributed to smectite. The peaks at $10.1 \AA, 5.02 \AA$ and $3.34 \AA$ were considered as the reflections of illite. The presence of kaolinite was identified by the peaks at $7.2 \AA, 3.58 \AA$ and $2.38 \AA$, as these peaks disappeared after heating to $550^{\circ} \mathrm{C}$. The identification of chlorite had to be based on the presence of reflections at $4.75 \AA$ and $3.55 \AA$, which still persisted after heating to $550^{\circ} \mathrm{C}$, and the resolvence of the chlorite (004) peak at $3.55 \AA$ from the kaolinite (002) peak at $3.58 \AA$, because the weak $14 \AA$ peak was masked by the reflection bands from mixedlayer minerals. An example of the X-ray identification of clay minerals is given on Fig. 2.

Clay mineral content down to $2 \%$ was semiquantitatively estimated by measuring the inten-

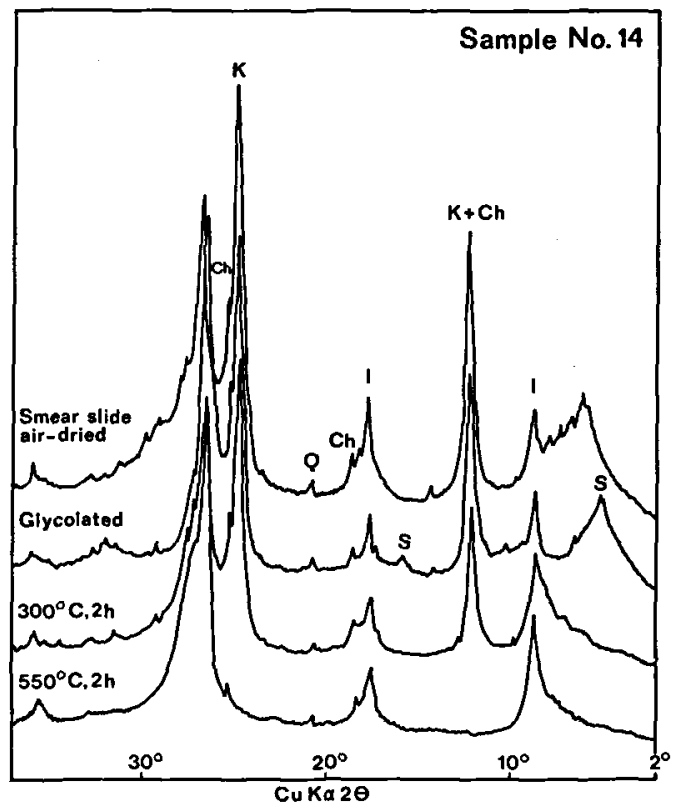

Fig. 2. The identification of clay minerals by X-ray diffractometry

S-smectite; I - illite; K - kaolinite; Ch-chlorite; Q-quartz. sity ratio of the basal reflections. The ratio of the amount of illite and smectite (including expandable mixed-layer minerals) was estimated by measuring the intensity ratio between the illite $10 \AA$ peak on the glycollated-diffractograms and the peak area of smectite obtained by subtracting this illite $10 \AA$ peak from the $10 \AA$ peak (illite + smectite) on the heated (to $550^{\circ} \mathrm{C}$ )-diffractograms. The amount of kaolinite and chlorite was estimated first by measuring the intensity ratio between $7 \AA$ and $10 \AA$ peaks on the glycollated-diffractograms, which was multiplied by 0.7 , and then by measuring the ratio of chlorite (004) to kaolinite (002).

\section{Results}

The Vertical distribution patterns of clay minerals

The vertical distribution patterns of clay minerals in the Paleogene deposits in borehole 83101 are mainly characterized by changes in the contents of smectite and kaolinite (Fig. 3). The Paleogene sediments are accordingly divided into two zones. Zone I includes the Upper Paleocene and the lowermost part of the Eocene (R1-R3 Beds). It is dominated by smectite $(83 \%$, on an average), with minor quantities of illite and traces of kaolinite. A local increase in the kaolinite content is present in the glauconitic silt layer (Fig. 3). Chlorite could only be traced in the Holmehus Formation and the Østerrende Clay. Zone II includes the Eocene sediments exclusive of R1-R3 Beds of the Røsnæes Clay Formation. It is mainly characterized by the distinct increase in kaolinite (from $3 \%$ in zone I to $21 \%$ in zone II) and the relative decrease in smectite (from $83 \%$ in zone I to $54 \%$ in zone II). Relatively high levels of kaolinite occur mostly in the middle and upper parts of the Røsnæs Clay Formation and the L1-L4 Beds of the Lillebalt Clay Formation (Fig. 3 ), while the content of smectite varies (from $25 \%$ to $75 \%$ ). Illite content tends to increase upwards at the expense of smectite. Chlorite occurs as a minor component (averaging $8 \%$ ). Kaolinite and chlorite contents tend to decrease upwards.

The vertical distribution of clay minerals in the equivalent sequences from other localities of 
Core 83101 Storebælt

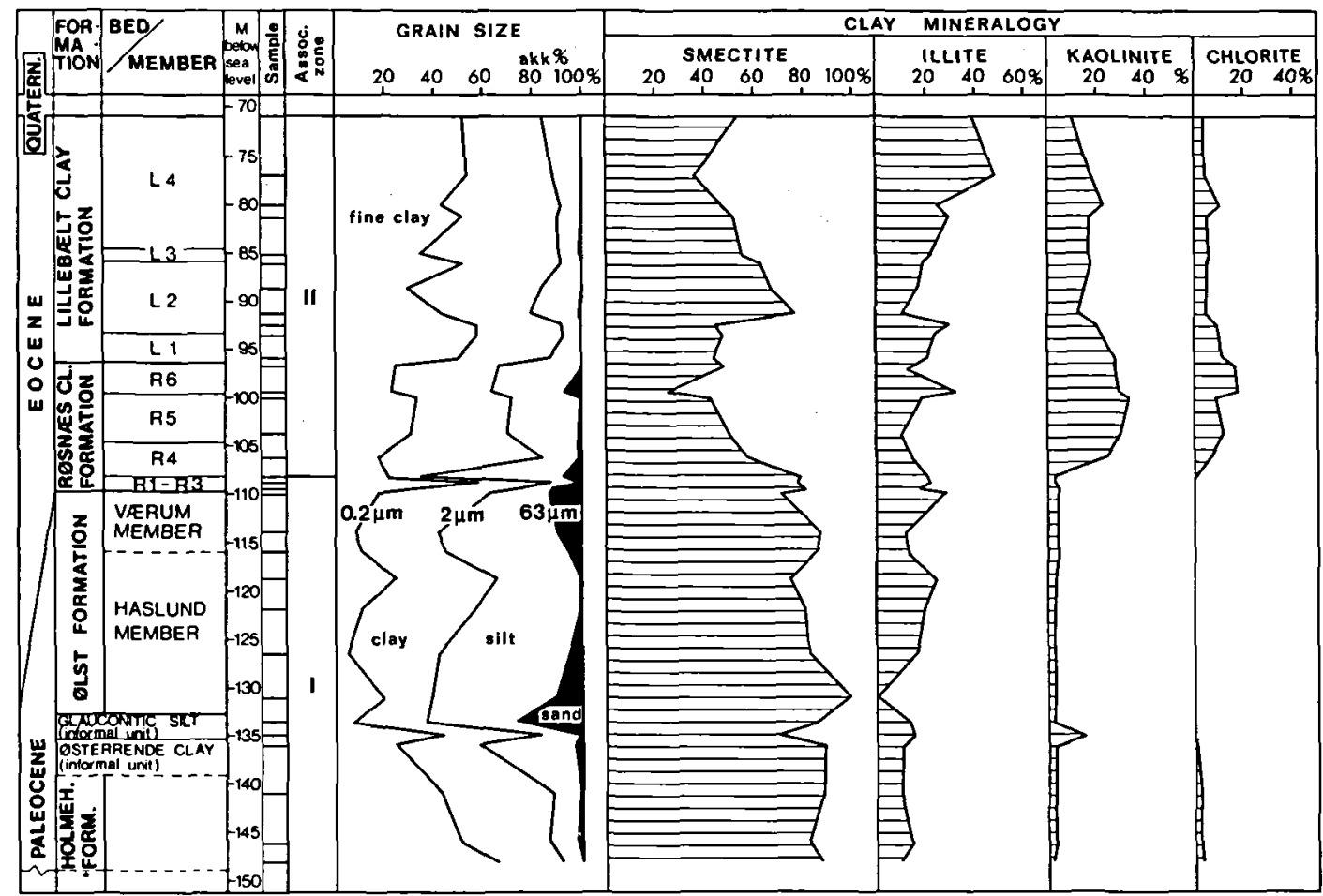

Fig. 3. The vertical distribution of clay minerals and grain size in Borehole 83101 .

Denmark (see Fig. 4) are also characterized by the predominance of smectite in the Upper Paleocene and by the introduction of a relatively high amount of kaolinite during the Eocene (Heilmann-Clausen et al., 1985). However, the vertical distribution patterns for these two minerals vary slightly at different localities. The pattern for illite does not change very much from one place to another. Chlorite has only been observed in borehole 83101 and in the Røjle area (Graff-Petersen, 1955). In addition, the transition from the clay mineral zone I to zone II is not in the same lithostratigraphical position at different localities. In the Ålbækhoved-northern Lillebælt area (Fig. 20 in Heilmann-Clausen et al., 1985), for example, the transition from zone I to zone II seems to be between the R2 and the R3-4 Beds, which is close to the transition in borehole 83101. In the Ølst area (see Fig. 19 in HeilmannClausen et al., 1985), on the other hand, the transition seems to be between the R5 and the R6 Beds. But, as mentioned by Nielsen et al. (1986), this might be due to lateral variations in facies.

\section{The regional distribution patterns of clay minerals}

Fig. 4. shows the regional distribution of clay minerals in four selected units: the Værum Member, the R5 Bed, the L3 Bed and finally the L5 Bed, which is not encountered in borehole 83101 . These units were considered to represent the sediments spanning in age from Late Paleocene to Early-Middle Eocene (Heilmann-Clausen et al., 1985).

As seen in Fig. 4a, the Værum Member of the $\emptyset$ Ist Formation is dominated by smectite, with a small amount of illite and trace of kaolinite. No significant change in clay mineral content is seen throughout the area shown in Fig. 4.

The smectite content decreases from the north towards the south and southeast in the R5 Bed of the Røsnæs Clay Formation, whereas kaolinite increases (Fig. 4b). Illite shows the same tendency as kaolinite, but its content is generally lower at most places. Chlorite has only been recognized in borehole 83101 . 


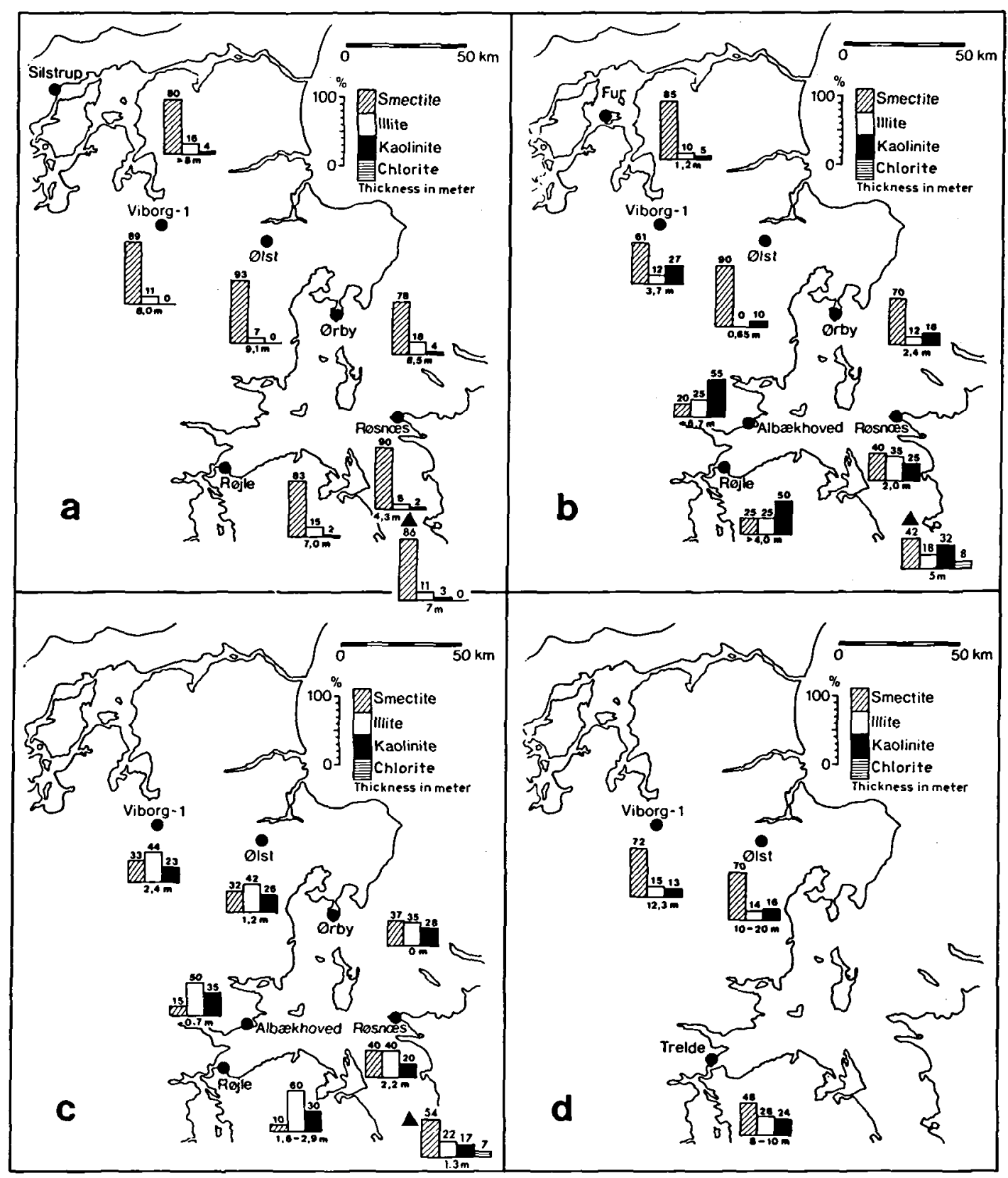

Fig. 4. The regional distribution of clay minerals

- after Heilmann-Clausen et al. (1985);

A - the present study on Borehol 83101.

a) the Varum Member, Ølst Formation

b) the R5 Bed, Røsnæs Clay Formation

c) the L3 Bed, Lillebælt Clay Formation

d) the L5 Bed, Lillebxit Clay Formation

The Ålbakhoved-northern Lillebalt area is the area from Røjle to Ålbakhoved.

The regional distribution pattern is almost the same in the L3 Bed of the Lillebælt Clay Formation as in the R5 Bed. The main differences are that the content of illite increases up to a higher level at the expense of smectite, especially towards the south (Fig. 4c), and becomes generally 
higher than that of kaolinite, and that the kaolinite content is more equal over the entire area.

Generally, the regional distribution patterns of clay minerals have no significant trend in the Upper Paleocene sediments but have a clear trend in the Eocene sediments. Smectite decreases from the north to the south and southeast, while kaolinite and illite increase.

\section{The relationship between the distribution of clay minerals and grain size in Borehole 83101}

The grain size distribution (down to $0.2 \mu \mathrm{m}$ ) of the Upper Paleocene and Eocene deposits in borehole 83101 is shown in Fig. 3. High contents of smectite correspond to high contents of clay fractions (more than $80 \%$ for the $<2 \mu \mathrm{m}$ fraction and $40 \%$ for the $<0.2 \mu \mathrm{m}$ fraction) in the Holmehus Formation. The content of smectite is still high in the Ølst Formation, but the content of clay fraction is lower, especially the $<0.2 \mu \mathrm{m}$ fraction, which is down to $13 \%$ on an average. It should be noted that in the $\varnothing$ lst Formation only about $25 \%$ of the clay fraction is smaller than 0.2 microns, while in the remaining sequence roughly half of the clay fraction is smaller than 0.2 microns. This is not reflected in the clay mineral composition. This will be discussed later. A similar relation also exists between grain size and clay mineral distribution published by Heilmann-Clausen et al. (1985).

\section{Interpretation and discussion}

The influence of the depositional environment on the clay mineral distribution.

The depositional environment of the Upper Paleocene and Eocene sediments was discussed by among others, Heilmann-Clausen et al. (1985) and Nielsen et al. (1986). According to them, they were deposited in a semi-enclosed shelf sea environment. The Røsnæs Clay was deposited in an oxic environment; the Holmehus Formation, in an oxic environment in the Røjle area and in an anoxic one around the $\emptyset$ sterrende (Nielsen et al., 1986). The environment was mainly anoxic during the deposition of the Ølst Formation and the Lower and Middle Lillebælt Clay.
No distinct relationship could be observed between the clay mineral distribution and the depositional environment in this study. Although the smectite content seems higher in an anoxic environment than in an oxic one, the same amount of smectite occurs in the both environments. For instance, the depositional environment of the Holmehus Formation in the Østerrende area differs from that at Røjle, but the smectite content of this formation is almost the same in both areas (Heilmann-Clausen et al., 1985). The smectite content varies even in the same environment, e.g. those of the paleocene sediments and the L1-L4 Beds of the Lillebælt Clay Formation (Fig. 3). The same phenomena have been observed for kaolinite and chlorite. It is therefore suggested that the variations in depositional environments (oxic and/or anoxic) may not be an important factor in determining the distribution of clay minerals.

\section{The influence of material source on the clay mineral distribution}

1. The source influencing the smectite distribution.

a. Volcanic material

The predominance of smectite in the uppermost part of Paleocene and the lowest part of Eocene sediments is considered to be chiefly caused by the alteration and/or weathering of pyroclastic material. This explanation is based on the occurence of high contents of smectite in association with numerous layers of volcanic ash in the Værum Member and the lower part of Røsnæs Clay (Heilmann-Clausen et al., 1985). However, the predominance of smectite extends into the Haslund Member, where very few ash layers have been observed (Heilmann-Clausen et al., 1985; Nielsen et al., 1986). The following hypothesis may explain this peculiarity. As mentioned above, the proportion of clay fraction smaller than 0.2 microns is clearly lower in the $\emptyset$ lst Formation than in the rest of the sequence. It is generally agreed that particles of smectite are smaller than other clay minerals, even when flocculated, and are mainly present in the finest part of clay fractions (Blatt et al., 1972, p. 374-384). The abnormal phenomenum observed in the $\emptyset$ lst Formation probably implies that some of the 
slightly coarser grains may have been smectitic. Valeton (1960) and Schöner (1960) have described aggregate grains larger than 6 microns consisting almost exclusively of smectite in chalk samples from $\mathbf{N}$. W. Germany. These aggregate grains were in fact the decomposed fragments of volcanic glass (Valeton, 1960). Furthermore, Schöner (1960) has shown that these aggregates are very resistant to disaggregation. It is therefore suggested that the occurrence of coarser but very smectitic sediments in the Ølst Formation could be due to the presence of fine-grained, weathered volcanic grains. In the Værum Member many discrete ash layers have been recognized, but only a few in the Haslund Member. The ash layers have not been included in the samples analyzed. In the upper part of the ØIst Formation of borehole 83101 burrows are occasionally present in some numbers and a mixing of volcanic ash layers and sediment seems therefore to be very likely. In the lower Haslund Member the presence of very fine laminations indicates the absence of a bioturbating benthic fauna. These facts, combined with the almost total absence of discrete volcanic ash layers, might indicate that the high content of smectite was due to the in situ alteration of volcanic dust. This is in agreement with the suggestion that the most likely volcanic source is the British-Faeroe area (Jacqué \& Thouvenin, 1975). But it should be remembered that the ash grains have not been identified yet in the Haslund Member. Furthermore, this hypothesis does not necessarily apply to the Holmehus Formation. The reason for this is given below.

The relative decrease in smectite content in the Eocene sediments could possibly be due to the general decrease in volcanic activity during the Eocene period and to the dilution caused by kaolinite and illite. This suggestion is based on the presence of only a few ash layers in most of the Eocene sediments (e.g. in borehole 83101, Nielsen et al., 1986) and the increase of kaolinite and illite relative to smectite.

\section{b. Carbonate terrain}

In the lower part of the Upper Paleocene sediments (the Holmehus Formation) almost no ash layers have been found. Only one layer of ash has been recorded at Holmehus by HeilmannClausen et al. (1985). Therefore, it seems unlikely that the high content of smectite in this part of the clay was caused by volcanic material alone. Tank (1963) suggested that the smectite clay with $10-20 \%$ of illite in the lower part of the Paleogene clays was mainly derived from the carbonate terrain bordering the southern North Sea Basin. Additional studies of the insoluble residues of the Upper Cretaceous chalk and Danian limestone seem to indicate that the clay mineral in these rocks is chiefly smectite with a variable amont of illite (Mainz, 1957; Weir \& Catt, 1965; Valeton, 1960; Jeans, 1968; Håkansson et al., 1974). So it seems possible that the insoluble residue of the carbonate terrain may be a source of smectite with minor illite.

c. Far transported suspended matter from the north-northwest

One further possibility is that, as in the Upper Cretaceous and the Lower Paleocene (Danian) (Håkansson et al., 1974), very little terrigenous material was washed into the North Sea Basin during the Upper Paleocene. This suggestion was supported by Gry's (1935) investigation of coarse particles in the lower part of the Upper Paleocene deposits of Denmark. The clay could, therefore, be far transported suspended matter, the same material as was deposited in the Viking Graben in the Paleocene (Nielsen et al., 1986), or it may have been derived from the volcanic area in the Scotland-Faeroe shelf region. The latter area was very active during the Thanetian (Jacqué \& Thouvenin, 1975). The presence of large amount of smectite in the Upper Paleocene Rogaland group sediments of the Viking Graben (Berstad \& Dypvik, 1982) would support this suggestion. The idea that suspended matter was transported from the north and northwest fits in with Bonde's (1974) palaeocurrent model during the Late Paleocene. He used this model to explain the deposition of the Moler (equal to the Fur Formation and the Balder Formation), which is contemporaneous with the Ølst Formation (Heilmann-Clausen et al., 1985). This model may or may not include the influence of differential flocculation and the size sorting of clay minerals, as proposed by Tank (1963).

2. The source influencing the distribution of kaolinite and illite

The distinct increase in amounts of kaolinite and illite during the Eocene could have resulted from 
the initiation of a clastic source to the south and southeast. The distribution patterns of these two minerals (Fig. 4b, c) would support this suggestion, which is the same as that proposed by Ziegler (see Encl. 24, 1982) for the clastic transportation. The source of the clay minerals could be the large kaolin-weathering area in the middle of Germany, where large swamps were transgressed near the Paleocene/Eocene boundary (Störr et al., 1968).

\section{The source of the chlorite}

The source for the chlorite is still in question. Berstad \& Dypvik (1982) reported chlorite in the Upper Paleocene and Lower Eocene clays from the Northern North Sea and considered them to be the alteration products of volcanic material under a tropical climate. According to them, a lot of chlorite should occur in the ash-bearing sequences. However, little or no chlorite has been found in the ash-bearing sequences of the Paleocene and Eocene sediments of Denmark. Malm et al. (1984) reported chlorite formed inside the volcanic grains from the Balder Formation in the North Sea region, but the mineral that has been identified on the edge of the grains was mixed-layer chlorite/smectite. Berner (1971) pointed out that chlorite can also be present as clay-sized grains derived from its pre-existing crystals. As mentioned above, no chlorite has been reported in the Paleocene and Eocene sediments, with the exception of Graff-Petersen's study (1955). The absence of chlorite may indicate that its dispersal was limited, or that it occurs in quantities under the detection limits for the older types of diffractometers.

\section{The influence of palaeoclimate on the clay mineral distribution}

The relation between clay mineralogy and climatic conditions has been investigated by many workers (e.g. Jackson, 1959; Grim, 1953; 1958; Biscaye, 1965; Griffin et al., 1963; 1968; ect.). According to them, kaolinite is usually facilitated in a warm and wet climate, while smectite can be facilitated in a variety of climates and latitudinal regimes, but usually in a cooler and drier climate. As mentioned above, kaolinite attains significant levels in the Eocene sediments, while it is almost negligible in the Upper Paleocene sediments where smectite is totally predominant (Fig. 3). This pattern has also been reported in the Tertiary sediments from other parts of the North Sea Basin by Nielsen (1979) and Berstad \& Dypvik (1982). This may indicate that the above pattern is widespread. It is therefore suggested that not only sediment source, but the changing climatic conditions during the Tertiary period, could also be an important factor, especially affecting the kaolinite distribution. This suggestion is further supported by the coincidence between the pattern above and the change in climatic conditions indicated by Strauch (1972), Buchardt (1978) and Hubbard et al. (1983). They reported that a subtropical climate prevailed in the Late Paleocene and a warm subtropical to tropical climate during the Early-Middle Eocene. A palaeotemperature curve of the North Sea, which was established by Buchard (1978) based on oxygen isotopes, further demonstrates that the temperature gradually increased from the Late Paleocene (about 10$15^{\circ} \mathrm{C}$ ) to Middle Eocene (abbout $25-30^{\circ} \mathrm{C}$ ) (Fig. 5). Nevertheless, it shoud be noted that relief, rainfall, drainage system, and the like are also important factors affecting the clay minerals (Grim, 1958; Berner, 1971).

The effect of climate on the smectite distribution is not revealed very clearly because of the influence of volcanism. But much higher content of smectite is also found in the non-ash-bearing se-

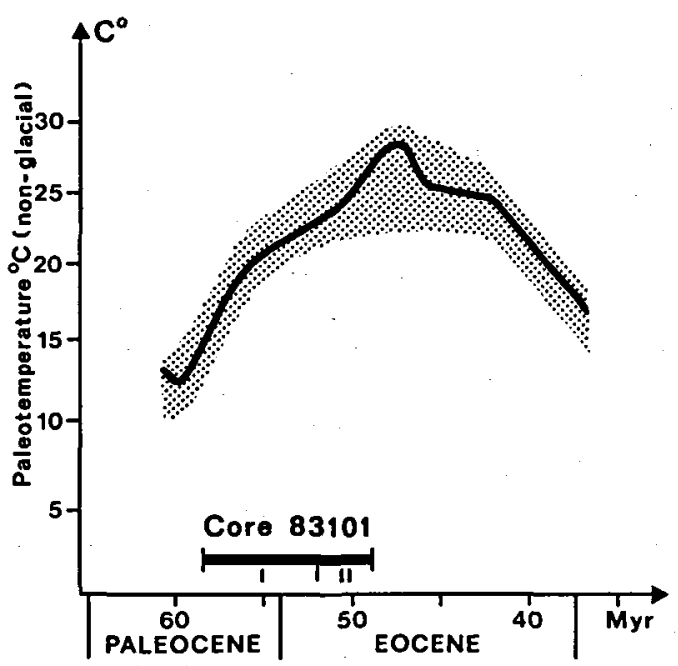

Fig. 5. The oxygen isotope palacotemperature curve of the Tertiary North Sea. (modified from Buchardt, 1978). 
quences of the Paleocene sediments than in the Eocene sediments. Even in the ash-bearing sequences (e.g. the Ølst Formation and the L2 Bed of the Lillebælt Clay Formation, Fig. 3), the smectite content is still slightly higher in the Paleocene than in the Eocene. This phenomenum has also been seen at other Danish localities (Heilmann-Clausen et al., 1985), thus indicating that although sediment source may be of major importance, lower temperatures in the Paleocene may also, to some extent, play a role.

\section{Conclusions}

The following conclusions can be drawn from the results obtained in this investigation:

Smectite is the predominant clay mineral in Danish Upper Paleocene sediments, illite and kaolinite being minor and trace components, respectively. In the Eocene sediments, the kaolinite content increases, while smectite decreases relatively. Illite content also shows a relative increase upwards.

Smectite content decreases, while kaolinite and illite increase from the north to the south and southeast in the Eocene. No clear trend of clay mineral distribution has been recognized in the Upper Paleocene.

The distribution patterns of clay minerals are probably chiefly influenced by the material source and the climatic conditions. The oxic and anoxic depositional environments do not seem to influence the clay mineral distribution. The high content of smectite is mainly attributed to the alteration and/or weathering of volcanic material, the smectitic clay from carbonate terrain and the far transported suspended matter from the northnorthwest. The change in climatic conditions may also influence the distribution of smectite, but it is probably less important than the material sources. The clastic source to the south and southeast and the change in climatic conditions during the Paleogene period may probably play an important role for the distribution patterns of kaolinite and/or illite.

Chlorite has not been reported in most of the previous studies. Even in this study, it has only been recognized in trace amount in the Holmehus Formation of the Paleocene and in minor amount in the Eocene. The question concerning its source is still open.
Acknowledgements. I am greatly indebted to B. Larsen (Institute for Applied Geology, Technical University of Denmark), who gave most valuable assistance and advice concerning the study of clay mineralogy and corrected the manuscript.

I am also very grateful to $\mathrm{O}$. B. Nielsen (Department of Geology, Aarhus University), who kindly contributed most important information and constructively criticised the manuscript.

Very important assistance has been given by $\mathrm{E}$. Leonardsen and Mrs. T. Poulsen (Geological Institute, University of Copenhagen), who carried out the X-ray diffractograms; and by Miss. I. Petersen (Institute for Applied Geology, Technical University of Denmark), who drafted the figures and maps. D. N. Penney (Department of Geology, Aarhus University) corrected the English of the text.

Lastly, I would like to thank the Danish Geotechnical Institute for kindly making the samples available for the study.

\section{Dansk sammendrag}

Lermineralogien i "plastisk ler« fra $\emptyset_{v r e}$ Paleocæn og Eocæn i boring 83101 fra Storebalt er unders $\varnothing \mathrm{gt}$. Smectit dominerer især i de paleocæne lag, i hvilke også mindre mængder af kaolinit, illit og chlorit er identificeret. I de eocære formationer optræder kaolinit i stigende mængde på bekostning af smectit. Chlorit er kun meget sporadisk forekommende. Sekvensen er opdelt i 2 zoner. Den nederste omfatter Holmehus- og Ølst Formationerne samt enhed R1-R3 fra Røsnæs Ler Formationen og er karakteriseret af en meget kraftig dominans af smectit med kaolinit som en meget underordnet komponent. Den øverste zone omfatter enhed R4-R6 fra Røsnæs Ler Formationen og enhed L1-L4 fra Lillebalt Ler Formationen og er karakteriseret af en markant forøgelse af kaolinit indholdet. I denne zone optræder tydelige regionale variationer. Således er smectitindholdet størst mod nordvest i Danmark, aftagende mod sydøst, medens kaolinit- og illitindholdet stiger i samme retning. Der er ikke observeret tilsvarende regionale forskelle i de paleocæene lag.

Variationer i kildematerialets sammensæatning, i klima og i aflejringsmiljø er diskuteret som mulige årsager til lermineralfordelingen. Smectit antages at stamme dels fra nedbrydning af vulkansk materiale, dels fra erosion af smectitholdige kalkaflejringer fra Danien og Øvre Kridt, dels som fjerntransporteret suspenderet materiale fra nordvest. Den markante stigning $i$ kaolinit indholdet $i$ den øvre zone antages at være forårsaget af en forøget tilførsel af forvitringsprodukter fra syd og sydøst samt af et relativt varmere klima. De forskellige aflejringsmiljøer synes derimod ikke at påvirke lermineralsammensatningen.

\section{References}

Berner, R. A. 1971: Principles of chemical sedimentology. New York: McGraw-Hill: 158-191.

Berstad, S. \& Dypvik, H. 1982: Sedimentological evolution and natural radioactivity of Tertiary sediments from the Central North Sea. J. Petrol. Geol. 5: 77-88.

Blatt, H., Middleton, G. \& Murray, R. 1972: Origin of sedimentary rocks. New Jersey: Prentice-Hall: 374-384.

Biscaye, P. E. 1965: Mineralogy and sedimentation of recent deep-sea clay in the Atlantic Ocean and adjacent seas and oceans. Bull. Geol. Soc. Amer. 76: 803-832.

Bonde, N. 1974: Palaeoenvironments as indicated by the "Mo 
Clay Formation" (Lowermost Eocene of Denmark). Tertiary Times 2 (1), 29-36.

Brindley, G. W. \& Brown, G. 1980: Crystal structures of clay minerals and their $X$-ray identification. London: Mineralogical Society. 495 pp.

Brown, G. 1961: The X-ray identification and crystal structures of clay minerals. London: Mineralogical Society. $544 \mathrm{pp}$.

Buchardt, B. 1978: Oxygen isotope palaeotemperatures from the Tertiary period in the North Sea area. Nature, 275, 121-123.

Gibbs, R. J. 1971: X-ray diffraction mounts. p. 531-539 In Garver, R. E., Editor: Procedures in sedimentary petrology. New York: Wiley-Interscience.

Graff-Petersen, P. 1955: Lillebxltsler. Bull. geol. Soc. Denmark. 13, 1-14.

Griffin, J. J. \& Goldberg, E. D. 1963: Clay mineral distributions in the Pacific Ocean. p. 728-741 In Hill, M. N., Editor: The sea. III. New York: Interscience Pub. 963 pp.

Griffin, J. J., Windom, H. \& Goldberg, E. D. 1968: The distribution of clay minerals in the world ocean. Deep-sea Res. $15,433-459$.

Grim, R. E. 1953: Clay mineralogy. New York: McGraw-Hill. 384 pp.

Grim, R. E. 1958: Cencept of diagenesis in argillaceous sediments. Bull. Assoc. Petrol. Geol. Amer. 42, 246-253.

Gry, H. 1935: Petrology of the Paleocene sedimentary rocks of Denmark. Danm. geol. Unders. (2) 61, 171 pp.

Heilmann-Clausen, C., Nielsen, O. B. \& Gersner, F. 1985: Lithostratigraphy and depositional environments in the Upper Paleocene and Eocene of Denmark. Bull. geol. Soc. Denmark. 33, 287-323.

Hubbard, R. N. L. B. \& Boulter, M. C. 1983: Reconstruction of Paleogene climate from palynological evidence. Nature. 301, 147-150.

Håkansson, E., Bromley, R. \& Perch-Nielsen, K. 1974: Maastrichtian chalk of Northwest Europe - a pelagic shelf sediment. Spec. Publs. Int. Ass. Sediment. 1, 211-233.

Jeans, C. V. 1968: The origin of montmorillonite of the European chalk with special reference to the lower chalk of England. Clay Minerals 7, 311-329.

Jackson, M. L. 1959: Frequency distribution of clay minerals in major great soil group as related to the factors of soil formation. p. 138-143 In Swineford, A., Editor: Clays and Clay Minerals. Proceedings of the Sixth National Conference. London: Pergamon Perss. $411 \mathrm{pp}$.

Jacqué, M. \& Thouvenin, J. 1975: Lower Tertiary tuffs and volcanic activity in the North Sea. Petroleum and Continental Shelf of North West Europe. Applied Science Publishers LTD. 1, 455-465.

Madirazza, I. \& Fregerslev, S. 1969: Lower Eocene tuffs at Mønsted, North Jutland. Bull. geol. Soc. Denmark. 19, 283-318.

Mainz, D. H. 1957: Über die mineralischen, nichtkarbonatischen Bestandteile des Cenoman und Turon der mit- teldeutschen kreidemulden und ihre verteilung. Heidel berger Beiträge Zur Mineralogie und Petrographie. 5, 302330.

Malm, O. A., Christensen, O. B., Furnes, H., Løvlie, R., Rueslâtten, H. \& Østby, K. L. 1984: The Lower Tertiary Balder Formation: An organogenic and tuffaceous deposit in the North Sea region. p. 149-170 In A. M. Spencer et al., Editor: Petroleum geology of the North European Margin. Norwegian Petroleum Society. Graham \& Trotman Ltd.

Nielsen, O. B. 1974: Sedimentation and diagenesis of Lower Eocene sediments at Ølst, Denmark. Sedimentary Geol ogy. 12, 25-44.

Nielsen, O. B. 1979: A sedimentological mineralogical investigation of the Tertiary sediments from the Borehole M-2X in Central Trough, North Sea. Danm. geol. Unders. Arbog, 41-50.

Nielsen, O. B., Baumann, J., Zhang Deyu, Heilmann-Clausen, C. \& Larsen, G. 1986: Tertiary sediments in Store Balt The Tertiary sediment of borehole D.G.I. 83101, Østerrende, Store Bælt, Denmark. Twentyfive years of geology in Aarhus. Geoskrifter, 32, 1986: 235-253.

Schöner, H. 1960: Über die Verteilung und Neubildung der nichtkarbonatischen Mineralkomponenten der Oberkreide aus der Umgebung von Hannover. Beitr. Miner. Petrogr. 7, 76-103

Stein, R. 1985: Rapid grain-size analysis of clay and silt fraction by Sedigraph 5000D: Comparison with coulter counter and Atterberg methods $J$. Sed. Petrol. 55, 590-593.

Strauch, F. Z. 1972: Zum Klimades nordatlantischskandischen Raumes im juengeren Kaenozoikum. Dtsh. Geol. Ges. Z. 123, I, 163-177.

Störr, M., Schwerdtner, G. \& Buchwald, J. 1968: Kaolinlagerstätten der Deutschen Demokratischen Republik. XXIII International Geological Congress. 15, 107-140.

Tank, R. W. 1963: Clay mineralogy of some Lower Tertiary (Paleogene) sediments from Denmark. Geological Survey of Denmark. IV series. 4, 9, 46 pp.

Thiede, J., Nielsen, O. B. \& Perch-Nielsen, K. 1980: Lithofacies, mineralogy and biostratigraphy of Eocene sediments in Northern Denmark (Deep Test Viborg 1). N. Jb. Geol. Paläont. Abh. 160, 149-172.

Unmack, A. 1949: X-ray investigation of some Danish clays: II, Montmorillonitic clays. Roy. Veter. Agric. Coll. Copenh. Yearbook 1949, 192-204.

Valeton, I. 1960: Vulkanishe Tuffiteinlagerung in der nordwestdeutchen Oberkreide. Mitt. geol. Stnst. Hamb. 29, 26-41.

Weir, A. H. \& Catt, J. A. 1965: The mineralogy of some upper chalk samples from the Arundel area, Sussex. Clay Minerals. 6, 97-110.

Ziegler, P. A. 1982: Atlas of Western and Central Europe. Enclosures 24. Shell International Petroleum Maatschappij B.V. 